\title{
Pendampingan Product Mix Sebagai Strategi Menghasilkan Benih Ciplukan Pada Usahatani Sawi Caisim Sistem Seri Di Kecamatan Lingsar
}

\author{
Tajidan, Arifuddin Sahidu, Lalu Wiresapta Karyadi, Suparmin
}

\author{
Program Studi Pengelolaan Sumberdaya Lahan Kering, Pascasarjana, Mataram University, \\ Mataram, Indonesia
}

\section{Alamat korespondensi : tajidan@unram.ac.id}

\begin{abstract}
ABSTRAK
Penerapan sistem tanam monokultur pada budidaya tanaman sawi memiliki risiko produksi, resiko harga dan resiko penghasilan. Resiko tersebut dapat diatasi dengan penerapan teknologi tanaman seri dan penerapan strategi produk campuran melalui diversifikasi tanaman dan sumber penghasilan. Tujuan yang hendak dicapai adalah menambah pengetahuan kelompok sasaran akan kandungan dan khasiat buah ciplukan bagi pemeliharaan kesehatan tubuh; menambah mengetahui petani tentang nilai ekonomi komoditas buah ciplukan; dan meningkatkan pengetahuan dan keterampilan petani tentang teknologi budidaya tanaman seri sebagai strategi menghasilkan buah dan benih ciplukan sebagai sumber penghasilan baru (product mix). Agar tujuan tersebut dapat tercapai maka dilaksanakan pengabdian kepada masyarakat dengan menggunakan metode pendidikan orang dewasa (andragogy) yaitu melakukan pendampingan kepada anggota kelompok tani yang mengusahakan tanaman sawi caisim. Sebagai entry point pendampingan adalah mengintroduksikan teknologi budidaya tanaman sawi caisim sistem seri, dan penanaman tanaman ciplukan dengan teknik polibag dan/atau sebagai tanaman penyangga tanaman sawi caisim sebagai upaya menghindari risiko produksi, resiko harga, dan resiko penghasilan. Hasil yang dicapai dari kegiatan pengabdian kepada masyarakat adalah: pengetahuan petani peserta pengabdian kepada masyarakat telah meningkat dari $61,9 \%$ menjadi $83,33 \%$ tentang pupuk dan teknik pemupukan tanaman sawi; dari 21 orang peserta yang hadir dalam kegiatan pengabdian kepada masyarakat diantaranya 30,16\% telah mengetahui manfaat ekonomi dan teknologi budidaya sistem tanam seri sawi caisim; buah dan benih ciplukan dapat diperoleh dari hasil budidaya menggunakan polibag atau tanam langsung di tanah dengan memanfaatkan lahan pekarangan yang terbuka dan memperoleh penyinaran matahari langsung, atau melalui diversifikasi tanaman sawi caisim dengan tanaman ciplukan.
\end{abstract}

Kata Kunci: Caisim, Campuran, Ciplukan, Khasiat, Penyangga

\section{PENDAHULUAN}

Tanaman ciplukan merupakan tanaman liar yang masih dianggap sebagai gulma oleh petani, sehingga keberadaannya semakin langka, sehingga tidak heran apabila buah ciplukan dijual dengan harga yang fantastis antara Rp 250.000 sampai dengan Rp 500.000 per kilogram (Muhlisin, 2019; Rachmawati, 2019). Tingginya harga buah ciplukan sebanding dengan khasiatnya bagi kesehatan tubuh manusia, yaitu sebagai bahan obat herbal tradisional. Buah ciplukan berkhasiat sebagai obat gusi berdarah dan obat mual, sementara daunnya berkhasiat sebagai obat bisul, borok dan peradangan kulit (Rachmawati, 2019).

Khasiat yang terkandung pada tanaman ciplukan tidak terlepas dari kandungan yang ada pada buah dan daunnya. Buah ciplukan mengandung antioksidan cukup tinggi. Diantara antioksidan yang ada dalam buah ciplukan adalah fenolik yang dapat mencegah kanker. Buah ciplukan kaya akan vitamin, diantaranya vitamin $A$, vitamin $C$, vitamin $D$ dan vitamin $K$. Vitamin A dapat menyehatkan mata, vitamin C memperbaiki metabolisme tubuh, vitamin D selain baik bagi tulang dan gigi, juga dapat mencegah penyakit degeneratif, sementara vitamin $\mathrm{K}$ berkhasiat dalam meningkatkan kesehatan reproduksi (Rachmawati, 2019). Kandungan senyawa yang ada pada buah ciplukan selain vitamin tersebut adalah chlorogenik acid, asam 
sitrat, alaidic acid, dan fisalin. Juga mengandung asam malat, tanin, alkaloid, kriptoxantin, dan gula. Kandungan senyawa tersebut selain sebagai asupan energi bagi tubuh, juga dapat merawat tubuh agar tetap bugar serta menimbulkan rasa bahagia.

Mahany (2016) yang dikutip dari Brilio.net melaporkan bahwa terdapat 16 manfaat dari buah ciplukan, yaitu mengobati penyakit jantung, obat asma, obat tekanan darah, obat stroke, obat kanker, obat kencing manis, serta berkhasiat sebagai penjernih kencing, menurunkan demam, menghilangkan kuning pada bayi, menambah kecerdasan, menghilangkan sakit persendian, menurunkan kolesterol, menambah darah dan sebagai penawar racun.

Khasiat dan manfaat tanaman ciplukan yang demikian banyak sebagaimana disebutkan di atas, juga Deviana (2019) melaporkan manfaat paling penting dari buah ciplukan adalah kandungan polifenol yang dapat menetralkan radikal bebas dalam tubuh, sekaligus melindungi tubuh dari berbagai penyakit degeneratif. Kandungan antioksidannya yang tinggi, sehingga dipercaya sebagai suplemen nutrisi yang ideal bagi kesehatan tubuh manusia, maka tidak mengherankan apabila memiliki nilai ekonomi tinggi (Muhlisin, 2019) dan dapat menghasilkan nilai tambah bagi petani dan para pelaku usaha dari hulu sampai hilir. Namun manfaat ekonomi tersebut belum dinikmati oleh petani karena belum dibudidayakan sebagai mana tanaman hortikultura pada umumnya. Selain karena belum adanya pengetahuan yang mendukung proses budidaya, juga belum tersedianya benih ciplukan.

Permasalahan kelangkaan benih merupakan permasalahan klasik yang selalu dihadapi oleh petani. Ketergantungan benih pada impor dan ketersediaan benih di pasar menjadi kendala peningkatan produksi. Tanaman ciplukan yang sudah tergolong langka, karena selalu dicabut oleh petani karena dianggap sebagai gulma atau tanaman pengganggu, sehingga sulit ditemukan di sawah sebagai tanaman liar. Dalam beberapa tahun terakhir, sejak tahun 2016, buah ciplukan dijual di mal dengan harga tinggi (Devina, 2019), maka tanaman ciplukan mulai dibudidayakan, namun petani pemula yang mencoba membudidayakannya terkendala karena ketiadaan benih.

Benih ciplukan tidak tersedia di Mataram atau kota lain dalam wilayah Nusa Tenggara Barat, sehingga harus didatangkan dari luar dengan mengorder melalui toko on-line. Penyediaan benih ciplukan dari toko on-line selain harganya relatif mahal, juga ada tambahan biaya ongkos kirim, juga membutuhkan waktu tunggu sampai tibanya benih tersebut ke alamat petani.

Persoalan benih dimungkinkan dapat teratasi melalui upaya kemandirian petani dalam pengadaan benih. Kemandirian petani dalam pengadaan benih merupakan tantangan sekaligus menjadi tugas perguruan tinggi untuk melakukan pendampingan agar petani dapat memenuhi kebutuhan benihnya, juga dapat memenuhi kebutuhan petani di sekitarnya. Introduksi teknologi budidaya tanaman ciplukan dimungkinkan diusahakan dengan sistem tanam monokultur, sebab tanaman ciplukan masih dianggap sebagai gulma yang tumbuh di antara tanaman lainnya (Deviana, 2019). Melalui budidaya monokultur, bahwa kesan sebagai gulma dapat dihindari, namun memiliki resiko yang lebih besar bila dibandingkan dengan sistem tanam tumpang sari. Oleh karena itu, solusi yang paling mungkin adalah mengusahakan tanaman ciplukan sebagai tanaman penyangga pada tanaman sawi caisim sistem tanam seri dan/atau diusahakan dengan menggunakan polibag yang dipelihara di lahan pekarangan.

1. Maksud Kegiatan

Maksud dilaksanakannya kegiatan pendampingan ini adalah untuk menyampaikan informasi dan teknologi budidaya tanaman seri sebagai suatu strategi menghasilkan buah dan benih ciplukan.

2. Tujuan Kegiatan

Tujuan yang ingin dicapai dalam pelaksanaan kegiatan pengabdian ini adalah:

a. Kelompok sasaran mengetahui kandungan pupuk dan teknik pemukan tanaman sawi caisim dan tanaman ciplukan; 
b. Petani yang tergabung dalam kelompok tani mengetahui manfaat ekonomi sistem tanam seri komoditi sawi caisim;

c. Petani sebagai peserta pendampingan memiliki pengetahuan dan keterampilan teknologi budidaya sistem tanaman seri sawi caisim dan tanaman ciplukan sebagai strategi menghasilkan buah dan benih ciplukan.

\section{Pendekatan}

\section{METODE PELAKSANAAN KEGIATAN}

Product mix (bauran produk) merupakan strategi mengatasi kemandekan pertumbuhan dan perkembangan produksi dan omzet penjualan. Bauran produk yang banyak diterapkan pada industri, kini diintroduksikan kepada petani yang mengusahakan tanaman hortikultura. Product mix adalah suatu upaya diversifikasi produk dalam upaya menyediakan turunan produk sejenis dan/atau menghasilkan produk lainnya dalam rangka memenuhi selera dan permintaan pasar yang kian beragam (Pahwa, 2019). Bauran produk sebagai strategi dinilai dapat diintroduksikan kepada petani sawi caisim yang tengah menghadapi masalah risiko produksi, risiko harga, dan risiko penghasilan.

Product mix terdiri atas 4 (empat) dimensi, yaitu breadth, length, depth, dan consistency. Breadth menunjukkan perbedaan jenis dari produk, misalnya sayuran daun, sayuran buah, sayuran bunga. Ditinjau dari segi length menggambarkan tentang aneka produk sejenis, misalnya sayuran daun terdiri atas : bayam, sawi, kol. Sayuran buah terdiri atas terong, mentimun, pare. Aspek depth dari bauran produk adalah masing-masing jenis produk, misalnya sawi terdiri atas sawi hijau, sawi putih, sawi huma, dan sawi caisim (sawi bakso). Sementara ditinjau dari konsistensinya adalah dilihat dari aspek citarasa misalnya sawi monumen, sawi keriting (Sutle cit. Seidel, 2019).

Mengingat bahwa tanaman ciplukan atau dalam bahasa daerah Suku Sasak disebut kenampokan, bukan merupakan tanaman asing, sebab masyarakat sudah mengenalnya sebagai tanaman liar yang tumbuh di antara tanaman semusim lainnya antara lain tumbuh pada tanaman bawang, cabe, tembakau dan lainnya di lahan yang tidak tergenang. Tanaman ciplukan juga dapat tumbuh pada pematang sawah atau pada ladang dan tempat terbuka lainnya (Pratama, 2019). Namun sebagai komoditi, buah ciplukan dianggap belum memiliki nilai ekonomi, karena belum diketahui khasiatnya bagi pemeliharaan kesehatan tubuh manusia. Seiring dengan perkembangan ilmu pengetahuan, maka buah ciplukan telah diketahui memiliki kandungan antioksidan yang berkhasiat dalam mencegah berbagai penyakit degeneratif. Oleh karena itu dalam upaya memperkenalkan bahwa buah ciplukan merupakan komoditas perdagangan yang bernilai ekonomi, maka pendekatan yang dilakukan adalah sebagai berikut:

1. Kunjungan ke tempat usahatani petani yang mengusahakan tanaman sawi caisim;

2. Mendapatkan informasi petani penggerak di desa atau ketua kelompok tani yang bersedia diajak bekerjasama mengenalkan tanaman ciplukan sebagai sumber pendapatan bagi petani di samping dari tanaman sawinya;

3. Melakukan pendampingan usahatani budidaya tanaman sawi caisim dengan sistem taman seri sebagai entry point dalam pengenalan tanaman ciplukan untuk menghasilkan buah dan benih ciplukan;

\section{Metode Pelaksanaan}

Pelaksanaan pendampingan menggunakan metode pendidikan orang dewasa (andragogy), yaitu suatu metode pembebasan dengan merekonstruksi pengetahuan dan pengalaman petani dalam berusahatani tanaman sawi caisim (Tajidan, et al, 2019). Prosedur pendidikan orang dewasa adalah sebagai berikut:

1. Metode Partisipatif 
a. Kunjungan ke kontak tani atau ketua kelompok tani untuk menyampaikan maksud dan tujuan penyelenggaraan pendampingan;

b. Melakukan negosiasi tentang penyelenggaraan pendampingan kepada anggota kelompok tani;

c. Menyepakati pembagian tugas dan peran antara kelompok tani dengan tim pelaksana pendampingan;

d. Menyusun jadwal pendampingan bersama tim pelaksana dan pengurus kelompok tani;

e. Menyepakati tempat pelaksanaan pendampingan dengan meminjam balai pertemuan atau aula Kantor Desa;

f. Menyepakati kontribusi pembiayaan antara tim pelaksana dengan kelompok tani;

g. Pendampingan dilaksanakan indoor dan outdoor. Indoor dilaksanakan di dalam ruangan, sementara pendampingan outdoor dilaksanakan di lahan pertanaman atau di lahan pekarangan sesuai dengan perjanjian yang disepakati.

h. Kegiatan monitoring dan evaluasi dilaksanakan dengan menggunakan instrumen yang disepakati bersama antara kelompok tani dengan tim pelaksana.

2. Pola Pendampingan

Dalam pendampingan melibatkan Penyuluh Pertanian Lapangan, Alumni yang sudah berhasil merintis usaha bidang hortikultura khususnya dalam distribusi benih dan pengadaan bibit tanaman hortikultura sayuran. Penyuluh dan alumni melakukan kunjungan ke lokasi kegiatan usahatani milik petani anggota kelompok, selanjutnya melakukan supervisi, saransaran, dan memberikan contoh penerapan teknologi budidaya sistem seri dan teknologi pembibitan tanaman ciplukan sebagai penghasil benih berkualitas. Pendampingan diikuti oleh mahasiswa sebagai proses belajar dalam rangka mempercepat penyelesaian studi dan memberikan pengalaman praktik penyuluhan di lapangan.

3. Pola Introduksi Teknologi

Teknologi budidaya tanaman sawi caisim yang diintroduksikan adalah teknologi budidaya sistem tanam sari dan introduksi sistem tanam menggunakan polibag dan tanaman penyangga untuk budidaya tanaman ciplukan.

4. Problem Solving

Petani yang tergabung dalam kelompok tani diberikan kesempatan konsultasi menggunakan media komunikasi telepon genggam (handphone) baik melalui pembicaraan langsung (calling), maupun secara tertulis menggunakan whatsapp dan/atau sms.

5. Pola Kolaborasi

Kegiatan pendampingan dimungkinkan bisa terlaksana apabila ada kolaborasi antara pemangku kepentingan (stakeholders). Kolaborasi akan dilaksanakan antara tim pengusul dengan Penyuluh Pertanian Lapang, Kelompok Tani dan Pemerintahan Desa. Pola kerjasama yang diterapkan adalah memberikan kesempatan kepada para pihak untuk aktif berpartisipasi sesuai tugas dan tanggung jawab masing-masing. Tim pengusul juga menjalin kerjasama dengan para mahasiswa untuk memberikan kesempatan pengalaman bekerja sebagai penyuluh, dan para alumni dapat berkontribusi dalam menularkan pengalaman bisnisnya, sekaligus sebagai media pembelajaran untuk meningkatkan kapasitas kewirausahaan mereka.

\section{Pelaksanaan}


a. Rapat Persiapan

Sehubungan dengan situasi bekerja dari rumah sebagai dampak dari Pandemi Covid-19, maka rapat dilaksanakan melalui jaringan komunikasi menggunakan aplikasi whatsApp.

Agenda Rapat adalah pembagian tugas, penentuan kelompok sasaran, penyusunan jadwal pelaksanaan, dan melakukan kunjungan dan negosiasi dengan kelompok sasaran, menyiapkan bahan dan alat, termasuk mendesain dan mencetak spanduk.

Hasil rapat adalah sebagai berikut:

1) Semua anggota tim bersedia melaksanakan tugas yang dibedrikan oleh Ketua Tim Pelaksana.

2) Pembagian tugas sebagai berikut: Penentuan kelompok sasaran dipercayakan kepada Ketua Tim Pelaksana, jadwal kegiatan ditetapkan setelah mendapat kesepakatan dengan Ketua Kelompok Sasaran; Kunjungan dan negosiasi dengan kelompok sasaran dilaksanakan pada minggu pertama bulan Juli 2020; Bahan dan alat disiapkan oleh Pengurus Kelompok Sasaran dengan bekerjasama dengan Petugas Lapang PT Pupuk Kaltim sebagai distributor pupuk; Design dan mencetak spanduk di Biro Reklame "Kubus".

b. Langkah Persiapan

1) Melakukan kunjungan dan observasi lokasi kegiatan Pengabdian Kepada Masyarakat di Dusun Bug-bug Utara

2) Mempersiapkan kelompok sasaran dengan merekrut dan mendata daftar nama anggota dan pemilihan Ketua Kelompok.

3) Melakukan kunjungan dan perkenalan dengan Manajer PT Pupuk Kaltim (Bpk Hidayat) di Kantornya di Jalan Sriwijaya dan menyepakati kerjasama pendampingan Kelompok Tani Sawi Caisim.

4) Membuat kesepakatan tentang metode dan pelaksanaan pendampingan antara tim pelaksana PKM, Petugas dari PT Pupuk Kaltim (Ziadi, SP) dan Kelompok Tani Sawi Caisim “ Ëmbun Pagi".

5) Membuat kesepakatan tentang waktu pelaksanaan kegiatan pendampingan di kelas dan pendamping lapangan teknik budidaya tanaman sawi sistem seri.

6) Menyusun Materi Pendampingan (Lampiran )

7) Menyusun Kisi-kisi Instrumen Monitoring dan Evaluasi (Lampiran )

8) Menyusun dan mengirim Undangan kepada ketua kelompok tani sawi.

c. Evaluasi Awal

Sebelum menyajikan materi pendampingan dilaksanakan, kepada peserta diminta untuk mengisi instrumen evaluasi awal dan mengisi daftar hadir.

2. Tahap Pelaksanaan

a. Observasi

Observasi adalah mengunjungi lokasi dan merekam kondisi faktual objek dengan mendeskripsikan dan mengamati langsung baik melalui penglihatan pandangan maupun perekamanan menggunakan visual dan video. Observasi dilakukan terhadap kondisi pertanian dan usahatani tanaman sawi caisim maupun dengan aktivitas petani tanaman sawi caisim di Dusun Bug-bug Utara.

Berikut ini adalah hasil rekaman visual kondisi tanaman dan usahatani tanaman sawi caisim 


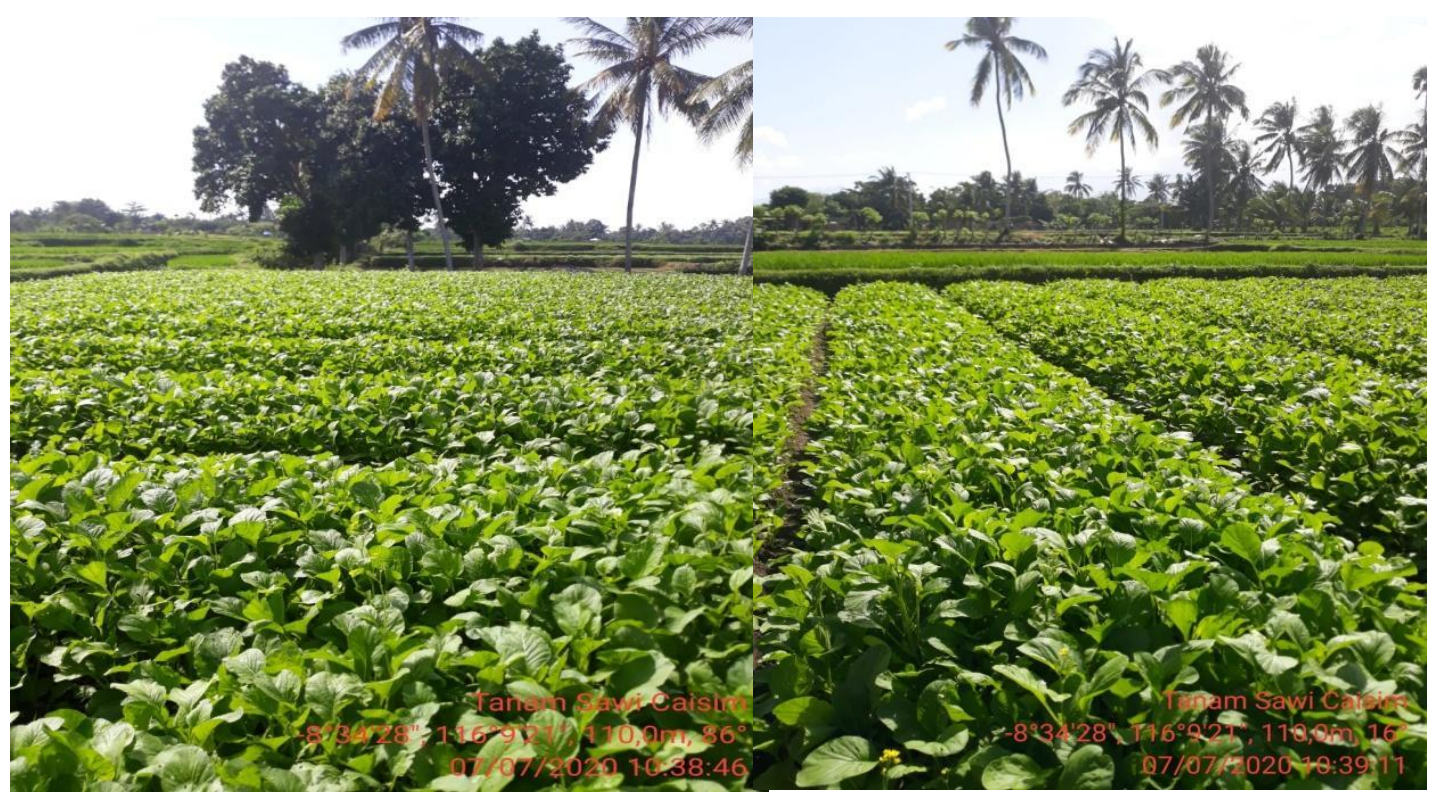

Foto 1. Kondisi Pertanaman Sawi Caisim sistem tanaman monokultur

Foto 2. Hamparan Pertanaman Sawi Caisim di antara pertanaman padi

b. Penyusunan Materi Pendampingan

1) Kandungan dan Khasiat Buah Ciplukan

Tanaman ciplukan memiliki banyak khasiat bagi kesehatan manusia, diantaranya berkhasiat menyembuhkan penyakit flu. Selain kaya nutrisi, buah ciplukan berkhasiat menyembuhkan flu.

Buah ciplukan kaya antioksidan, sehingga dapat melindungi tubuh dari serangan flu dan batuk, berarti buah ciplukan dapat meningkatkan daya tahan tubuh terhadap serangan flu, batuk dan bronchitis.

Selain berkhasiat meningkatkan daya tahan tubuh dari serangan flu, batuk dan bronchitis, buah ciplukan juga mengandung serat larut yang bermanfaat bagi pasien kadar gula darah tinggi. Bukan hanya itu, karena buah ciplukan mengandung phytochemical seperti polifenol dan karoten, cape gooseberry berfungsi mengatur tekanan darah, serta menjaga kadar kolesterol dalam darah.

2) Nilai Ekonomi Komoditi Buah Ciplukan

Oleh karena khasiat buah ciplukan banyak khasiatnya bagi kesehatan, maka tidak heran jika buah ciplukan dibutuhkan banyak orang, sementara belum banyak yang membudidayakannya. Kesenjangan yang lebar antara jumlah produksi dan kebutuhan, maka harga buah ciplukan relatif mahal. Harga buah ciplukan berkisar Rp 37.500 sampai Rp 54.990 per 250 gram berat atau dapat mencapai Rp250.000/kg (m.tokopedia.com), bila diecer harganya mencapai Rp 500 sampai Rp 1000 per buah dan harga buah ciplukan sangat bervariasi tergantung di mana dijual.

3) Teknologi Budidaya Tanaman Sawi Caisim Sistem Tanaman

Materi pendampingan product mix tanaman sawi caisim sistem tanam seri untuk meghasilkan benih ciplukan disusun oleh tim pelaksana. Ringkasan Materi Budidaya Tanaman Ciplukan sebagai berikut

(https://www.infoagribisnis.com/2018/01/budidaya-ciplukan/):

a) Syarat Tumbuh

Tanaman ciplukan dapat tumbuh dalam kondisi tanah yang subur maupun tanah yang kurus. Idealnya tanaman ciplukan tumbuh subur pada tanah yang gembur, tidak tergenang, dan memiliki $\mathrm{pH}$ netral dan struktur tanah yang remah. Tanaman 
ciplukan tumbuh di daerah tropis mulai dari dataran rendah hingga dataran medium sampai dengan $1.500 \mathrm{~m}$ dari permukaan laut( dpl).

b) Teknik Budidaya

1) Benih

Benih tanaman ciplokasi dapat dihasilkan dari biji. Biji ciplukan terdapat dalam buah yang sudah matang berwarna orange atau kuning kemerah-merahan. Biji ciplokasi dikeluarkan dari buah dengan cara membelahnya dan menekannya hingga , dikeluar bijinya. Biji dibersihkan dari cairan buah, dicuci, dan dikering anginkan.

2) Bibit

Biji ciplukan disemai pada bak, polibag, atau bedengan semai. Ditunggu beberapa hari untuk dapat diperoleh perkecambahan. Setelah bibit berumur 30 sampai dengan 45 hari, maka tanaman dapat dipindahkan ke lahan tanam.

3) Pembuatan Media Tanam

Tanaman ciplukan dapat ditanam pada lahan tanam atau menggunakan media tanam pada pot atau polibag. Penanaman pada lahan tanam dilakukan dengan mempersiapkan lahan tanam dengan membuat bedengan. Tanah digemburkan dan diratakan, dibuatkan selokan agar air tidak tergenang. Bila penanaman akan dilakukan di pot atau polibag, maka disiapkan media tanam dari campuran tanah dan pupuk kandang. Tanah diayak terlebih dahulu, selanjutnya dicampur dengan pupuk kandang dengan perbandingan yang seimbang yaitu 2:1. .

4) Tanam

Bila media tanam telah siap, maka dilakukan penanaman bibit, sementara media tanam ditekan agar tanaman tegak. Pot atau polibag yang telah ditanami dengan bibit ciplukan ditempatkan pada ruang yang tidak terkena matahari langsung di pekarangan rumah atau di ladang / tegal.

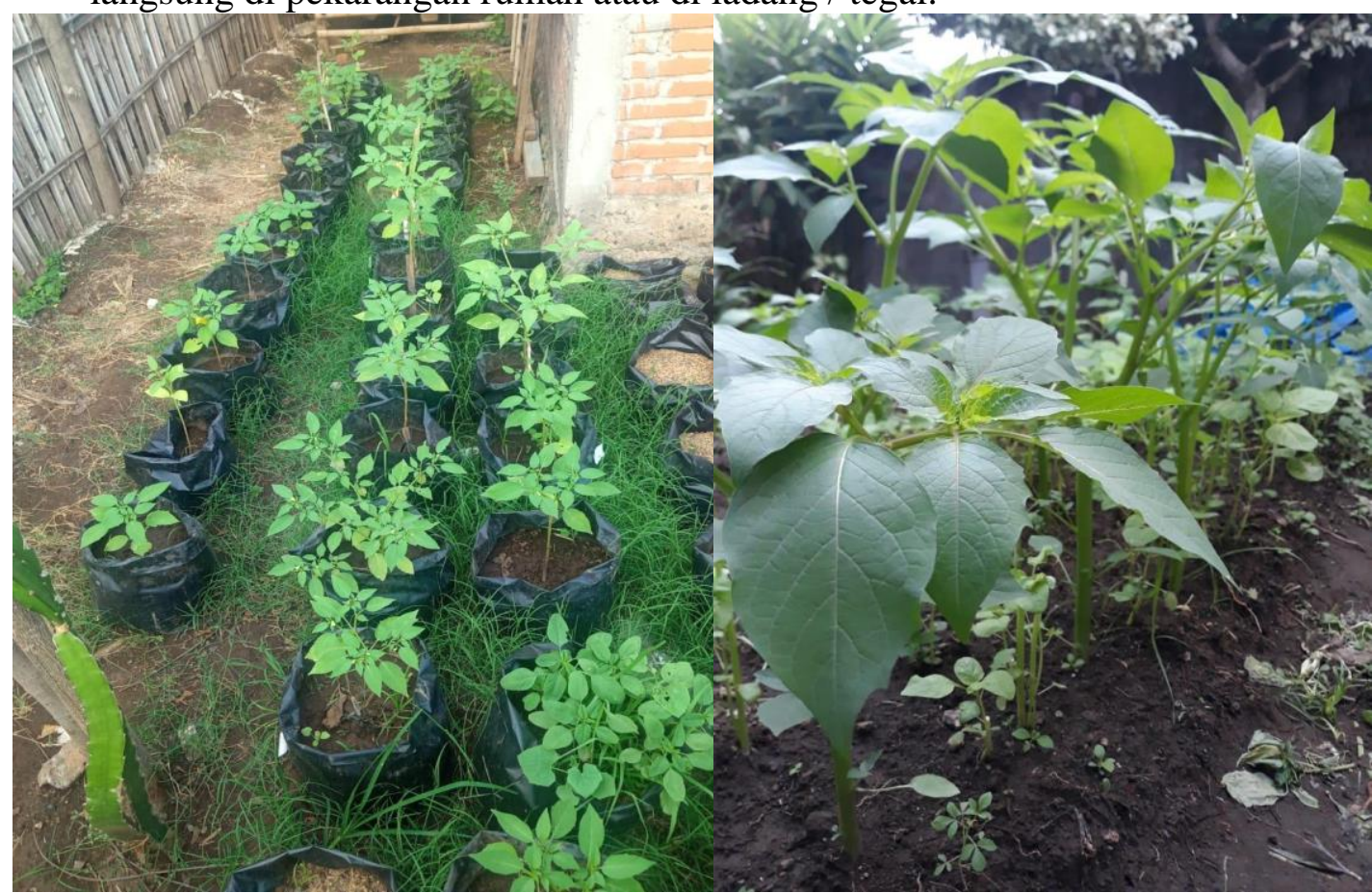

Foto-3 Penanamn Ciplukan menggunakan polibag di pekarangan
Foto-4 Tanaman Ciplukan tumbuh subur di pekarangan

5) Perawatan Tanaman 
Pada awal pertumbuhan agar dilakukan perawatan tanaman. Perawatan tanaman dilakukan dengan penyiraman rutin setiap sore dengan volume air yang cukup. Pemupukan dilakukan secara berkala baik pupuk organik dan pupuk NPK yang dilarutkan dalam air. Pemupukan NPK dilakukan dengan penyiraman. Bila ada serangan hama penyakit, maka lakukan pengendalian baik secara manual atau mekanik menggunakan pestisida nabati atau kimia tergantung intensitas serangan.

6) Panen

Panen dilakukan 3 sampai 4 bulan setelah tanam. Panen dilakukan setelah buah matang. Kelopak buah berwarna kuning atau oranye. Panen dapat dilakukan selektif, yaitu hanya buah yang matang saja yang dipanen, sementara buah yang belum matang dibiarkan sampai matang, sebab buah ciplukan tidak matang serentak.

Sistem tanam diversifikasi selain mengurangi resiko usahatani seperti risiko harga, resiko pendapatan, juga sebagai sumber penghasilan harian, sumber penghasilan mingguan, dan sumber penghasilan bulanan. Selain pemanfaatan bedengan, juga diversifikasi dapat memanfaatkan pematang dengan tanaman tahunan seperti pisang dan pepaya sebagai sumber penghasilan musiman atau tahunan. Selain memanfaatkan pematang, diversifikasi juga dapat dilakukan dengan memanfaatkan lahan pekarangan atau bagian yang kosong dari pekarangan seperti pinggir tembok atau samping rumah dengan syarat ada ruang yang kena sinar matahari langsung. Penanaman ciplukan dimungkinkan menggunakan polibag sebagaimana telah dilakukan di pekarangan (Foto-3).

Dari hasil percobaan menunjukkan bahwa tanaman ciplukan tumbuh subur apabila ditanam langsung di tanah daripada menggunakan polibag sebagaimana tampak pada Foto-13 dan Foto4.

3. Tahap Monitoring dan Evaluasi

a. Monitoring

Monitoring terdiri atas monitoring internal dan monitoring eksternal. Monitoring internal dilaksanakan oleh tim pelaksana atau tim internal Universitas Mataram. Monitoring disebut juga pemantauan yaitu suatu penilaian atas pelaksanan pekerjaaan dengan berpodoman pada rencana kegiatan atau usulan (proposal) kegiatan. Monitoring internal dibuat dalam bentuk catatan harian (log book). Sementara monitoring eksternal dilaksanakan oleh pihak tim khusus yang bentuk oleh LPPM Universitas Mataram. Sampai saat laporan ini disusun belum dilaksanakan kegiatan monitoring eksternal. Sebagai penyebabnya diduga karena adanya Pandemi Covid-19. Sambil menunggu pengumuman resmi direncanakan pelaksanaan seminar hasil pengabdian kepada masyarakat.

b. Evaluasi

1) Evaluasi Awal

Evaluasi awal terdiri atas evaluasi kognitif yang terkait langsung dengan benih, pupuk dan pemupukan, dan sistem tanam seri, serta product mix atau diversifikasi. Pengetahuan tentang proses perlakuan terhadap benih sebelum ditanam. Pengetahuan pupuk meliputi jenis pupuk, kandungan pupuk, dan penggunaan pupuk dasar, serta pengertian dan manfaat sistem tanam seri dan product mix. 


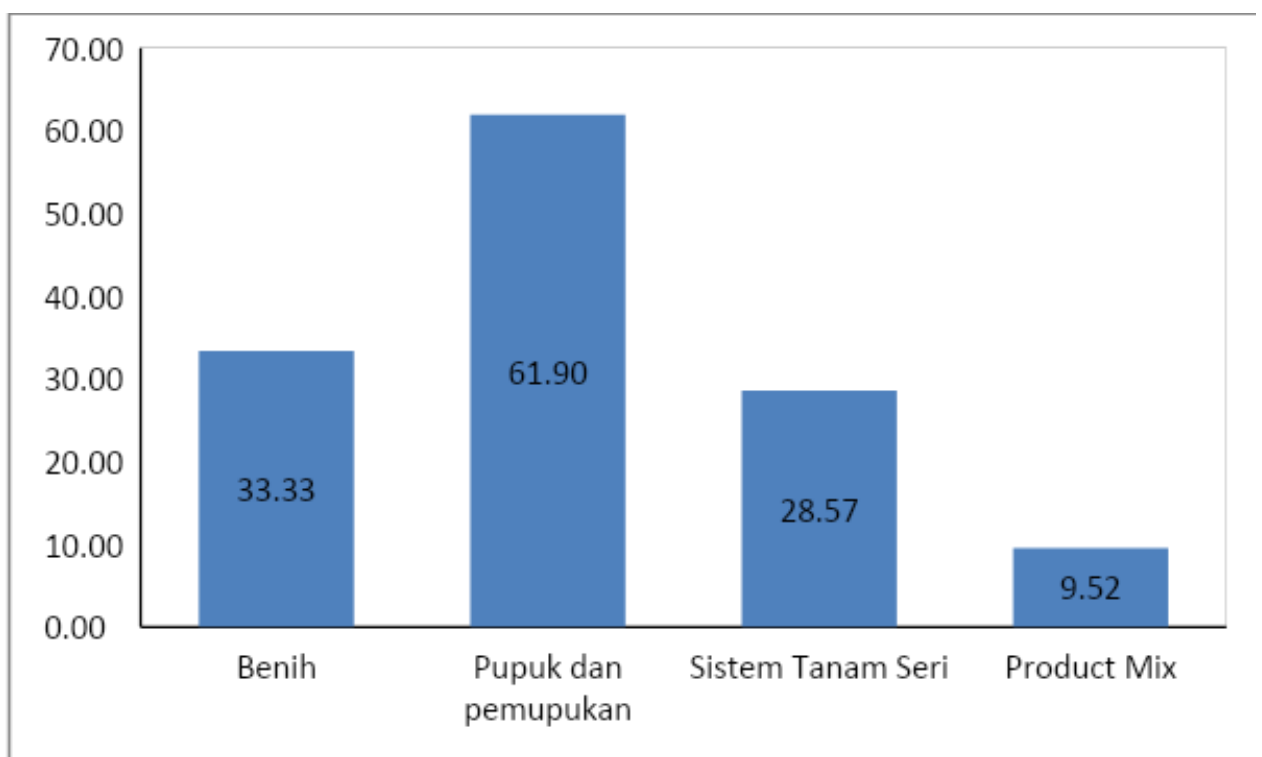

Gambar 1. Hasil Evaluasi Tes Awal

Tes awal menunjukkan bahwa sebagian besar peserta memiliki pengetahuan tentang pupuk dan pemupukan, namun sebagian kecil yang mengetahui tentang benih, sistem tanam seri dan product mix (diversifikasi) sebagaimana tampak pada Gambar 4.1. Peserta sangat sedikit yang mengetahui tentang sistem tanam seri dan product mix, artinya materi yang disuguhkan merupakan hal yang baru bagi mereka, karena sebagian besar dari peserta belum memiliki pengetahuan. Dengan demikian, topik PKM dinilai sangat tepat, karena belum diketahui dan belum diterapkan dalam berusahatani.

2) Evaluasi Akhir

Pada akhir penyampaian materi dilaksanakan evaluasi akhir. Evaluasi akhir bertujuan untuk mengetahui sejauh mana peserta dapat menyerap pengetahuan yang sudah diberikan kepada mereka. Dengan menggunakan instrumen evaluasi yang sama antara evaluasi akhir dengan evaluasi awal, maka dimungkinkan untuk diketahui sebesar perubahan pengetahuan sebelum dan sesudah diberikan materi pengabdian kepada masyarakat. Hasil evaluasi awal (Gambar 1) dibandingkan dengan hasil evaluasi akhir (Gambar 2), apabila hasil evaluasi akhir lebih baik daripada hasil evaluasi awal, maka materi yang disampaikan oleh tim pelaksana dapat diserap oleh peserta.

Hasil evaluasi akhir lebih baik daripada hasil evaluasi awal, maka dapat disimpulkan bahwa ada peningkatan pengetahuan peserta antara sebelum dan sesudah penyampaian materi pengabdian kepada masyarakat. 


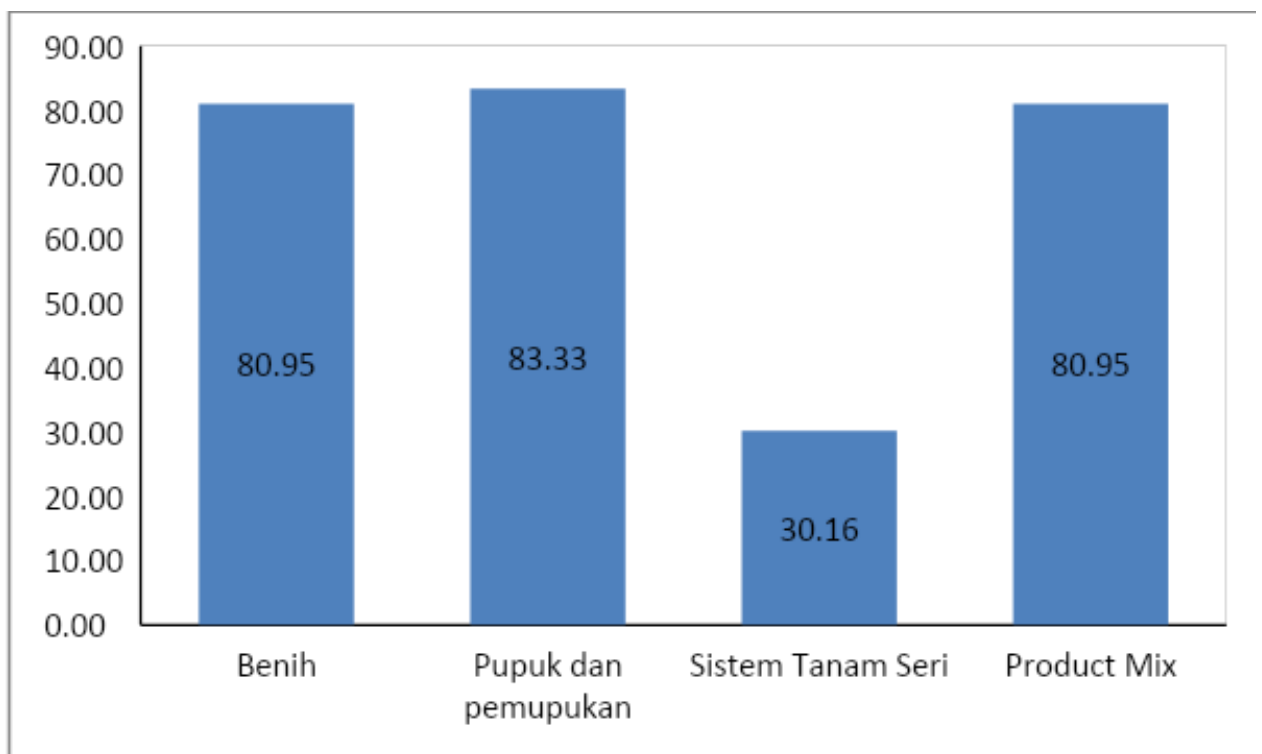

Gambar 2. Hasil Evaluasi Akhir

Sangat banyak persentase peserta yang pengetahuannya meningkat tentang benih dan product mix, namun peningkatannya relatif sedikit pada aspek sistem tanam seri. Jadi peningkatan pengetahuan pada sistem tanam seri relatif sedikit. Hal ini memberi indikasi bahwa peserta belum banyak yang paham tentang sistem tanam seri, sehingga belum dapat diyakini bahwa sistem tanam seri belum dapat diterapkan dalam waktu dekat. Solusinya adalah meningkatkan pengetahuan, pemahaman, dan keterampilan para petani melalui demplot agar para petani dapat belajar dan menerapkannya di dalam berusahatani.

\section{Hasil Pelaksanaan dan Pembahasan}

1. Budidaya Tanaman Sawi Caisim Sistem Tanam Seri

Pengetahuan tentang sistem tanam seri masih sangat minim dibandingkan pengetahuannya tentang pupuk dan pemupukan, dan pengetahuannya tentang benih. Peserta banyak yang belum paham tentang sistem tanam seri, bahkan boleh dikata masih asing bagi sebagian besar peserta. Dari 21 peserta yang ikut evaluasi awal menunjukkan bahwa 28,57\% yang pernah mendengar dan mengetahui tentang sistem tanam seri (Gambar 4.1). Setelah materi disampaikan tentang sistem tanam seri, yang pernah mendengar dan mengetahui sistem tanam seri meningkat menjadi 30,16\% (Gambar 4.2). Peningkatan ini relatif kecil bila dibandingkan dengan peningkatan pengetahuan lainnya. Dari 21 orang peserta, kira-kita 7 (tujuh) orang yang dapat mengetahui tentang sistem tanam seri tersebut. Oleh karena itu, tim pelaksana menilai masih diperlukan langkah-langkah konkrit untuk meningkatkan pengetahuan dan pemahaman tentang sistem tanam seri melalui pendampingan lapangan agar mereka dapat paham dan dapat mengimplementasikannya, sehingga memberi peluang bagi para petani memperoleh penghasilan secara rutin setiap pekan atau setiap minggu. 


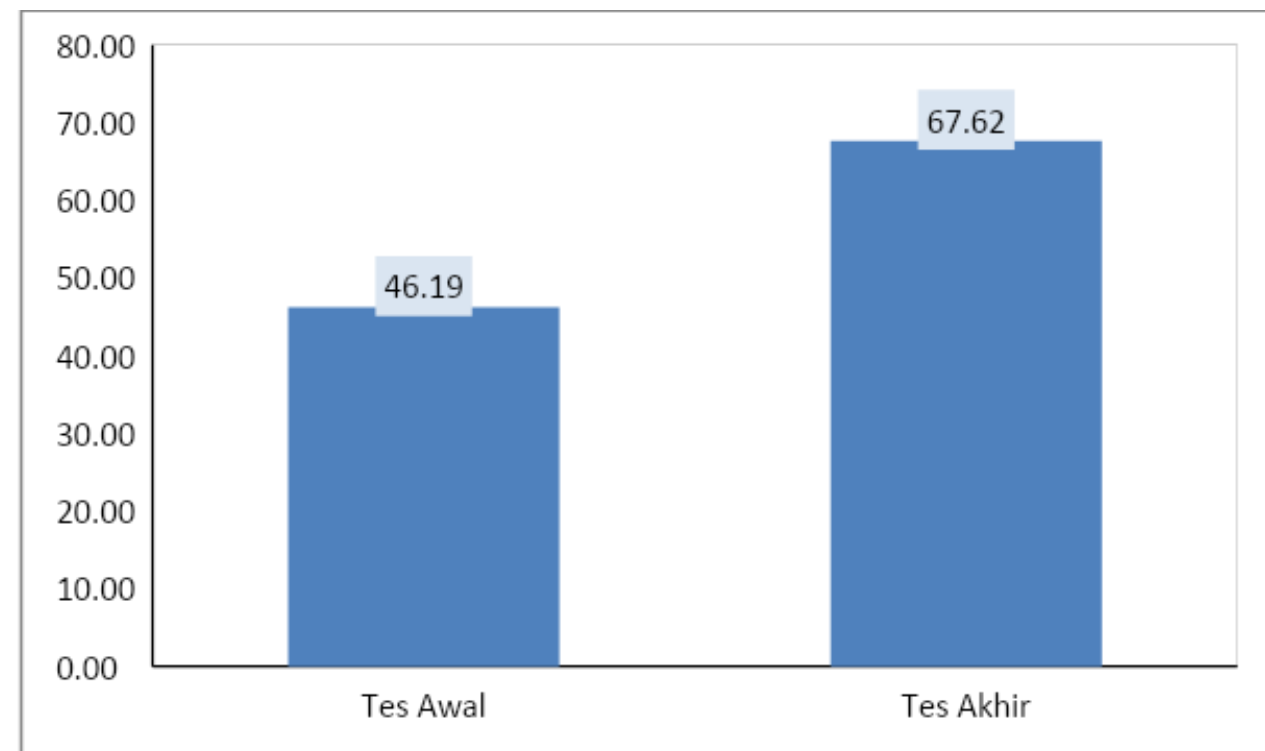

Gambar 3. Rata-rata Nilai Evaluasi Awal dan Nilai Evaluasi Akhir

Secara umum bahwa rata-rata nilai evaluasi akhir lebih tinggi dari rata-rata nilai evaluasi awal, artinya telah terjadi peningkatan pengetahuan dari sebelum penyampaian materi dibandingkan setelah pemberian materi. Secara umum menunjukkan bahwa para peserta mendengar dan memperhatikan materi PKM yang disampaikan oleh tim pelaksana. Peningkatan nilai evaluasi antara setelah dan sebelum penyampaian materi sebesar $21,43 \%$.

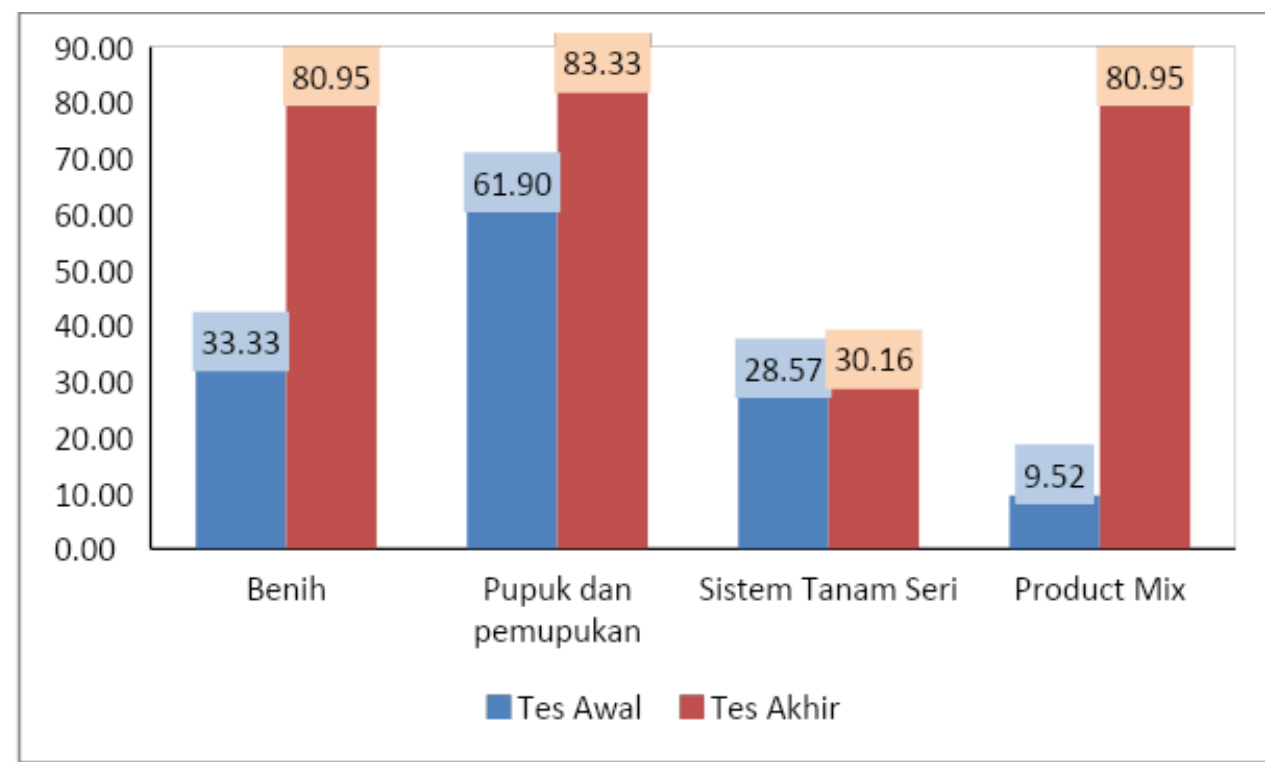

Gambar 4. Rata-rata Nilai Evaluasi Awal dan Nilai Evaluasi Akhir

Peningkatan persentase peserta yang memiliki pengetahuan tampak pada semua aspek yaitu benih, pupuk dan pemupukan, sistem tanam seri dan product mix. Aspek peningkatan terbesar pada product mix, sementara peningkatn yang paling sedikit pada asek sistem tanam seri. Hal ini diduga, karena selama ini mereka selalu berusaha tani dengan sistem tanam monokultur dan tanam serempak, sistem tanam seri tidak pernah dibayangkan apalagi diterapkan. Bagaimana sistem tanam seri itu belum terbayang sama sekali, apalagi mengetahui dan menerapkannya. Product mix atau sistem tanam diversifikasi sudah biasa mereka terapkan, 
misalnya selain menanam kacang tanah, juga menanam jagung, atau menanam cabe dan terong atau tomat, sehingga product mix sudah familier bagi sebagian besar jumlah petani.

2. Product Mix Sawi Caisim dan Ciplukan

Berbeda dengan sistem tanam seri, pada evaluasi awal bahwa peserta yang mengetahui tentang product mix atau diversifikasi mencapai angka 9,52\%, setelah diberikan penjelasan, pengetahuan peserta pada akhir penyampaian materi meningkat menjadi $80,95 \%$ artinya dari 21 orang peserta sekitar 19 orang yang mengetahui artinya terjadi peningkatan jumlah peserta dari 2 (dua) orang peserta meningkat menjadi 21 orang peserta atau bertambah 17 orang, suatu peningkatan yang signifikan. Oleh karena itu, peluang penerapan product mix atau diversifikasi lebih besar daripada sistem tanam seri.

\section{Hasil Benih Ciplukan}

Produksi benih dihasilkan dari buah bididaya ciplukan di pekarangan yang ditanam di langsung di tenah dan polibag. Berikut ini ditampilkan foto buah dan benih ciplukan yang dihasilkan dari budidaya ciplukan di lahan pekarangan:

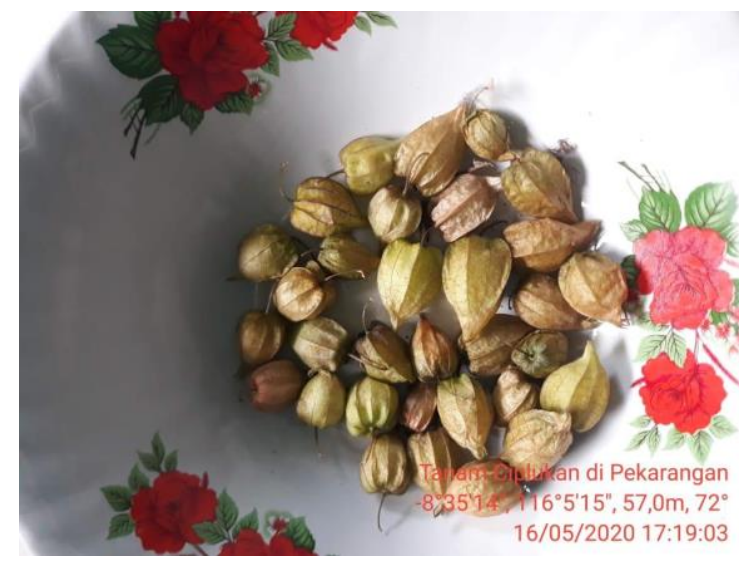

Foto-5 Hasil panen buah ciplukan

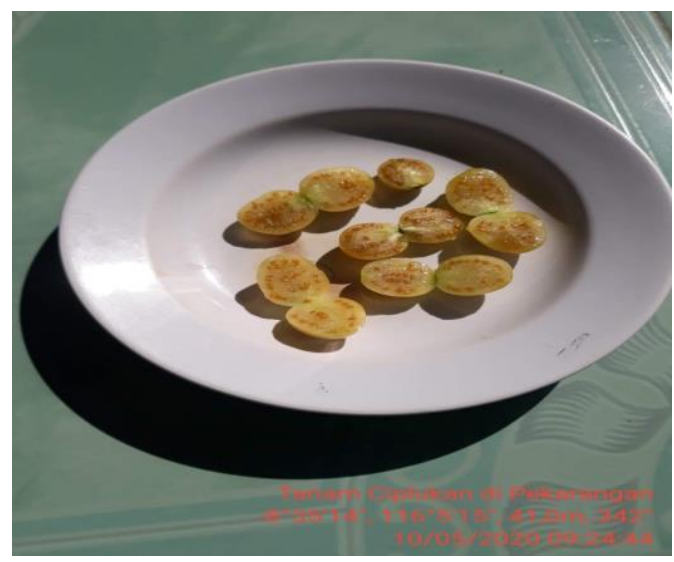

Foto-6 Buah ciplukan yang sudah dibelah untuk dikeluarkan bijinya

Kulit buah ciplukan dibuka, buahnya dikeluarkan, selanjutnya dibelah dua dan diukur diameternya. Buah ciplukan yang relatif besar, yaitu yang berdiameter lebih dari $15 \mathrm{~mm}$, disisihkan untuk digunakan sebagai bakal benih, sementara yang diameter kurang dari $15 \mathrm{~mm}$ disisihkan. Biji buah ciplukan yang relatif besar dikeluarkan dan dijemur di bawah terik matahari selama 2 sampai 3 hari. Biji yang sudah kering dikemas menggunakan alumunium foil, selanjutnya disimpan di tempat yang kering dan tidak kena sinar matahari langsung. Bila dibutuhkan untuk ditanam, maka benih diambil, selanjutnya direndam selama 4-5 jam, dan selanjutnya disemai. 


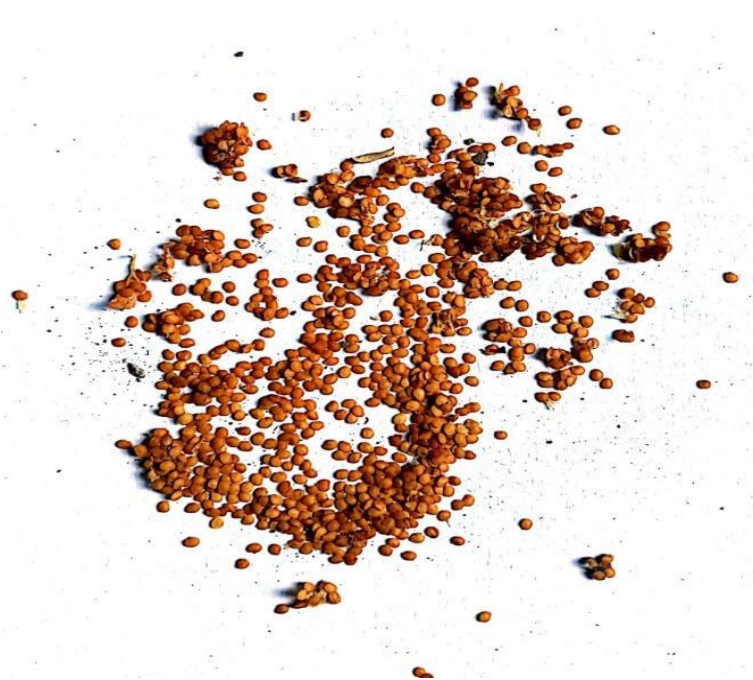

Foto 7. Benih Ciplukan yang siap disemaikan

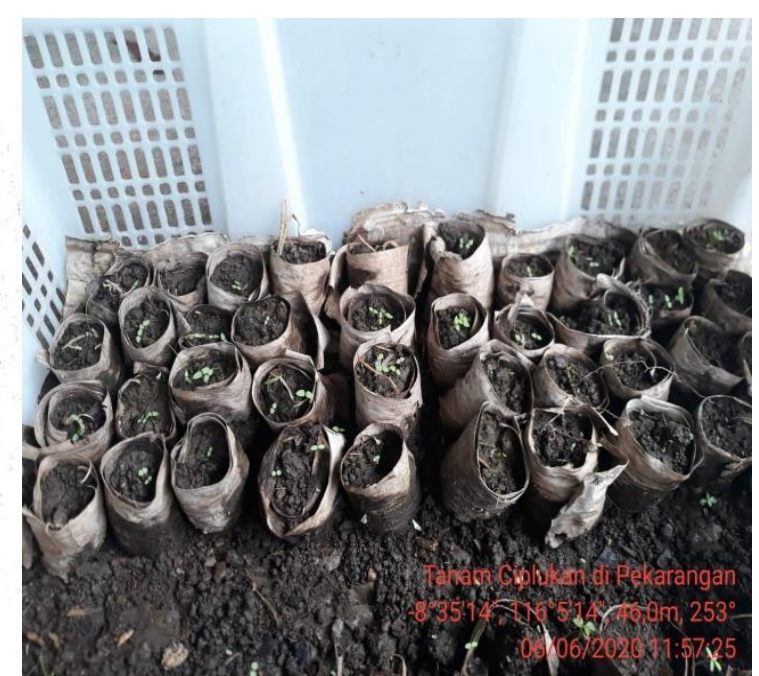

Foto 8. Persemaian Tanaman Ciplukan

Biji ciplukan berwarna kuning pucat ketika masih basah, setelah proses pengeringan selama 2 sampai 3 hari warnanya berubah menjadi coklat (Foto 17) Biji ciplukan yang sudah kering disimpan beberapa minggu sebelum disemaikan untuk melewatkan masa dormansinya. Masa dormansi benih ciplukan minimal 2 (dua) minggu agar dapat tumbuh dengan baik. Sebelum disemaikan sebaiknya benih ciplukan direndam 4-5 jam. Pada Foto 18 tampak bibit ciplukan yang siap berumur satu minggu dengan daya tumbuh lebih dari $80 \%$.

\section{Kesimpulan}

\section{KESIMPULAN DAN SARAN}

1. Pengetahuan petani peserta pengabdian kepada masyarakat telah meningkat dari $61,9 \%$ menjadi $83,33 \%$ tentang pupuk dan teknik pemupukan tanaman sawi;

2. Dari 21 orang peserta yang hadir dalam kegiatan pengabdian kepada masyarakat diantaranya $30,16 \%$ telah mengetahui manfaat ekonomi dan teknologi budidaya sistem tanam seri sawi caisim;

3. Buah dan benih ciplukan dapat diperoleh dari hasil budidaya menggunakan polibag atau tanam langsung di tanah dengan memanfaatkan lahan pekarangan yang terbuka dan memperoleh penyinaran matahari langsung, atau melalui diversifikasi tanaman sawi caisim dengan tanaman ciplukan.

\section{Saran}

1. Kegiatan pendampingan perlu dilanjutkan dengan metode demplot untuk meningkatkan pemahaman dan penerapan sistem tanam seri komoditas sawi caisim.

2. Diharapkan kepada petugas Penyuluh Pertanian Lapang (PPL) agar mendorong petani sawi caisim menerapkan diversifikasi usaha (product mix) untuk mengurangi risiko harga, risiko biaya, dan risiko pendapatan.

3. Pertumbuhan tanaman ciplukan lebih baik ditanam langsung di tanah daripada ditanam di polibag, oleh karena itu kepada petani disarankan agar tanaman ciplukan ditanam langsung di tanah daripada menggunakan polibag.

4. Kepada petani disarankan untuk merendam benih 4 sampai 6 jam sebelum disebar di petak persemaian. 


\section{DAFTAR PUSTAKA}

Deviana, I., 2019. Rupanya 8 Khasiat Ini Yang Bikin Buah Ciplukan Yang Kini Dijual Mahal. IDN Times. https://idntimes.com.

Muhlisin, A., 2019. Manfaat Daun dan Buah Ciplukan Beserta Efek Sampingnya. Honestdocs Editorial Team.www.honestdocs.id

Pahwa. A, 2019. What is Product Mix ? Explanation with Example. Product Mix In Marketing. https://www.feedough.com.

Pratama, N, 2019. Manfaat Buah Ciplukan Yang Dulu Dicampakkan, Kini Diburu dan Harganya Selangit. Tribun Kaltim. https:kaltim.tribunnews.com.

Rachmawati, N., 2019. 20 Manfaat Buah Ciplukan Untuk Kesehatan Yang Jarang Diketahui. https://m.bola.com.

Tajidan, FX Edy Fernandez, Halil, dan Efendy, 2019. Pendampingan Pembiayaan Pada Pengembangan Agroindustri VCO di Desa Sokong Kecamatan Tanjung. Program Studi Agribisnis, Jurusan Sosial Ekonomi, Fakultas Pertanian, Lembaga Penelitian dan Pengabdian Kepada Masyarakat Universitas Mataram. 